Working Paper 2010:14

Department of Economics

\title{
Labor-Force Participation Rates and the Informational Value of Unemployment Rates: \\ Evidence from Disaggregated US Data
}

Magnus Gustavsson and Pär Österholm 
Department of Economics

Working paper 2010:14

Uppsala University

August 2010

P.O. Box 513

ISSN 1653-6975

SE-751 20 Uppsala

Sweden

Fax: +46184711478

Labor-Force Participation Rates and the Informational Value

of UnemPloyment RATES: EVIDENCE FROM Disaggregated US DATA

Magnus Gustavsson and Pär Österholm

Papers in the Working Paper Series are published on internet in PDF formats.

Download from http://www.nek.uu.se or from S-WoPEC http://swopec.hhs.se/uunewp/ 


\title{
Labor-Force Participation Rates and the Informational Value of Unemployment Rates: Evidence from Disaggregated US Data* $^{*}$
}

\author{
Magnus Gustavsson ${ }^{\#}$ \\ Department of Economics, Uppsala University \\ and \\ Pär Österholm* \\ National Institute of Economic Research
}

\begin{abstract}
The informational value of the aggregate US unemployment rate has recently been questioned because of a unit root in the labor-force participation rate; the lack of mean reversion implies that long-run changes in unemployment rates are highly unlikely to reflect long-run changes in joblessness. This paper shows that this critique also extends to unemployment rates for sub-populations, such as prime-aged males.
\end{abstract}

JEL Classification: C22, E24, J21

Keywords: Mean reversion, Unit-root test

\footnotetext{
* We are grateful to Meredith Beechey for valuable comments on this paper. Financial support from Jan Wallander's and Tom Hedelius' Foundation is gratefully acknowledged.

\# Department of Economics, Uppsala University, Box 513, 75120 Uppsala, Sweden e-mail: magnus.gustavsson@ @ek.uu.se Phone: +4618 4711103

* National Institute of Economic Research, Box 3116, 10362 Stockholm, Sweden

e-mail: par.osterholm@konj.se Phone: +46 84535972
} 


\section{Introduction}

Much research has relied upon aggregate unemployment rates as a measure of labor market conditions or the state of the labor market. For example, studies of the connection between macroeconomic conditions and income inequality, and the empirical literature on the economics of crime frequently adopt this interpretation. ${ }^{1}$ However, the informational value of unemployment rates has been seriously questioned during the last decade due to changes in labor-force participation rates. For example, due to large withdrawals of low-skilled men from the labor force in the United States, Murphy and Topel (1997, p. 295) claimed that "the unemployment rate has become progressively less informative about the state of the labor market". Furthermore, Krugman (2004) argued that the decline in the US unemployment rate from its peak in mid-2003 was partially driven by lower participation rates. A recent illustration of this issue was provided on September 7, 2007 when the Bureau of Labor Statistics declared that the US unemployment rate was unchanged between July and August but that the labor force had declined by almost 600000 individuals.

In a recent study, Gustavsson and Österholm (2006) raised further doubts about the informational value of unemployment rates by demonstrating that aggregate laborforce participation rates in the United States, Canada and Australia are unambiguously generated by unit-root processes. The unit-root finding means that it is highly uncertain what is reflected by the long-run dynamics of unemployment rates. Only when participation rates are stationary are long-run changes in employment guaranteed to carry over one-for-one to unemployment. Thus, focusing on unemployment rates alone is likely to distort inference about the state of the labor market, and the distortion could be in either direction. ${ }^{2}$ Accordingly, the unit-root

\footnotetext{
${ }^{1}$ See, for example, Blinder and Esaki (1978), Gould et al. (2002) and Jacobson (2004).

${ }^{2}$ To clarify, consider the unemployment rate, $U R=U /(U+E)$, where $E$ and $U$ are individuals recorded as employed and unemployed in the official statistics, respectively, and the participation rate $P R=(E+U) / P O P$, where $P O P$ is the relevant population. A one-time permanent shift in the participation rate through a decrease in $U$ will permanently lower the unemployment rate even though the employment rate is unchanged. A permanent shift in the participation rate through a decrease in $E$, on the other hand, will permanently raise the unemployment rate, but by less than if the flow is from $E$ to $U$.
} 
finding casts doubt on the conclusions of previous research that uses time series of unemployment as a measure of labor market conditions. ${ }^{3,4}$

A limitation of Gustavsson and Österholm's (2006) study is that it only investigates the aggregate participation rate. Because women have accounted for a majority of the dynamics in the participation rate in the post-war period (Jaumotte, 2003), it could be the case that the male participation rate is mean reverting, and that male unemployment rates constitute reliable measures of males' labor market situation. This also appears to be a common belief, as many studies that use unemployment as a measure of labor market conditions choose to focus on male, or prime-aged male, unemployment; see, for example, Jännti (1994), Parker and Preston (2005) and Autor et al. (2007). As an illustrative example, consider Fairlie and Sundstrom (1999, p. 252); in their study of racial differences in unemployment in the United States between 1880 and 1990, they focus on male unemployment rates "because dramatic changes in the labor-force participation rates of women, as well as racial differences in participation, pose serious questions about the reliability of unemployment rate trends and comparisons for women.". 5

In this paper we show that resorting to unemployment rates for sub-populations does not overcome the problems of non-stationary participation rates in the US economy. Employing three different unit-root tests, we find unequivocal evidence for the presence of a unit root in a large set of disaggregated participation rates by combinations of gender, race and age - even when allowing for a deterministic trend. The traditional assumption that only female labor-force participation is a

\footnotetext{
${ }^{3}$ Obviously, a unit root in participation rates does not per se cast doubt on studies that use the unemployment rate to capture what it is likely to measure well: the share of the labor force that fulfill the criteria of not having a job, being available for work and actively looking for work. Such information is expected to be highly relevant in many applications, for instance in studies on nominal wage and inflation pressure in a Phillips curve setting; see, for example, Cahuc and Zylberberg (2004).

${ }^{4}$ The problems associated with a unit root in participation rates are especially severe for empirical studies of unemployment hysteresis. As highlighted by Gustavsson and Österholm (2007), part of this literature tends to use unemployment rates as a direct measure of employment. Such a one-to-one relationship between unemployment and employment is extremely unlikely to be true with a unit root in the participation rate.

${ }^{5}$ Note, however, that Fairlie and Sundstrom (1999) also employ an alternative measure of joblessness.
} 
"complicated" variable is accordingly overly simplistic and may induce false conclusions.

\section{Empirical findings}

Monthly data on labor-force participation rates were provided by the Bureau of Labor Statistics. The following series were analyzed: the aggregate participation rate; the male and female participation rates; the participation rates for whites, white men and white women; the participation rates for blacks, black men and black women; the participation rates for young (aged 16 to 24 ), prime aged (25 to 54) and middle aged (55 to 64); the participation rate for young, prime-aged and middle-aged men; and, finally, the participation rate for young, prime-aged and middle-aged women. The span of the data is January 1948 to August 2007 for all series, except when the population has been divided by race; for white and black subpopulations the samples are January 1954 to August 2007 and January 1972 to August 2007, respectively.

We initially employ three different univariate unit-root tests which are popular in the literature and have well-established empirical properties: the Augmented DickeyFuller test (Said and Dickey, 1984), the Augmented Dickey-Fuller (ADF) test with GLS detrending (Elliot et al., 1996) and the KPSS test (Kwiatkowski et al., 1992). ${ }^{6}$ As is well known, the first two tests have a unit root under the null whereas the KPSS test has stationarity under the null hypothesis. This "reversed burden of proof" of the KPSS test could be useful since the power of the ADF and ADF-GLS tests is not very high when the data-generating process has a root that is very close to - but less than unity. Employing these three tests, we test for mean reversion to a constant level; results for all tests shown in Table 1 . As can be seen, the evidence for non-stationarity is overwhelming. All three tests agree that all investigated series are generated by

\footnotetext{
${ }^{6}$ Lag length in the ADF test and ADF test with GLS detrending (ADF-GLS) is determined using the Hannan and Quinn (1979) information criterion.
} 
unit-root processes. In other words, the evidence against stationary labor-force participation rates is abundant. ${ }^{7}$

Table 1. Results from unit-root tests on participation rates.

\begin{tabular}{|c|c|c|c|c|}
\hline Participation rate & ADF & ADF-GLS & KPSS & Sample \\
\hline Overall & -1.459 & 1.284 & $3.120^{* *}$ & 1948M01-2007M08 \\
\hline Men & -0.162 & 1.583 & $3.117^{* *}$ & 1948M01-2007M08 \\
\hline Women & -1.760 & 1.243 & $3.186^{* *}$ & 1948M01-2007M08 \\
\hline White & -2.170 & 1.055 & $2.950^{* *}$ & 1954M01-2007M08 \\
\hline White men & -0.549 & 2.194 & $2.735^{* *}$ & 1954M01-2007M08 \\
\hline White women & -2.526 & 1.602 & $2.965^{* *}$ & 1954M01-2007M08 \\
\hline Black & -1.667 & 0.258 & $2.062^{* *}$ & 1972M01-2007M08 \\
\hline Black men & -0.985 & -0.989 & $2.133^{* *}$ & 1972M01-2007M08 \\
\hline Black women & -1.961 & 0.986 & $2.424^{* *}$ & 1972M01-2007M08 \\
\hline $16-24$ & -1.198 & -0.826 & $2.156^{* *}$ & 1948M01-2007M08 \\
\hline $25-54$ & -1.687 & 1.855 & $2.139^{* *}$ & 1948M01-2007M08 \\
\hline $55-64$ & -0.932 & -0.167 & $0.477^{*}$ & 1948M01-2007M08 \\
\hline Men 16-24 & -0.779 & -1.107 & $2.643^{* *}$ & 1948M01-2007M08 \\
\hline Men 25-54 & 0.576 & 1.976 & $3.078^{* *}$ & 1948M01-2007M08 \\
\hline Men 55-64 & -1.298 & 1.283 & $3.001^{* *}$ & 1948M01-2007M08 \\
\hline Women 16-24 & -1.324 & 0.291 & $2.831^{* *}$ & 1948M01-2007M08 \\
\hline Women 25-54 & -1.562 & 1.191 & $3.179^{* *}$ & 1948M01-2007M08 \\
\hline Women 55-64 & -1.316 & 2.967 & $2.728^{* *}$ & 1948M01-2007M08 \\
\hline
\end{tabular}

ADF is the Augmented Dickey-Fuller test of Said and Dickey (1984). ADF-GLS is the Augmented Dickey-Fuller test with GLS detrending of Elliot et al. (1996). KPSS is the KPSS test of Kwiatkowski et al. (1992). Entries in the table are test statistics. ${ }^{* *}$ significant at the $1 \%$ level; ${ }^{*}$ significant at the $5 \%$ level.

\footnotetext{
${ }^{7}$ It can be noted that we have also conducted all of the analysis in the paper on the logistic transformation of all participation rates. This transformation is given by $\tilde{p}_{t}=\ln \left(p_{t} /\left(1-p_{t}\right)\right)$, where $p_{t}$ is a participation rate. This sensitivity analysis is motivated by the econometric criticism that a variable that is bounded between zero and one - such as the participation rate - strictly speaking cannot be a linear unit-root process with an additive error term fulfilling standard assumptions; see, for example, Nicolau (2002). The transformed variable $\tilde{p}_{t}$, on the other hand, is unbounded above and below and one therefore does not have to say that the unit-root assumption relies on approximations. Employing this approach for bounded data was originally suggested by Wallis (1987). Results from using the logistic transformation of the participation rates - not reported but available upon request - are quantitatively very similar and qualitatively identical to when we use the untransformed participation rates.
} 
We are aware that the absence of mean reversion could owe to a deterministic trend in the data rather than a stochastic trend, especially for women where there has been a marked upward trend in labor-force participation rates since the 1960s (OECD, 1994). Thus, we test for reversion around a linear trend before concluding that the absence of mean reversion identified in Table 1 is due to a unit root. Specifically, we apply the ADF, ADF-GLS and KPSS tests to our eighteen labor-force participation rates, allowing for a deterministic trend unique to each series. The results are shown in Table 2.

Table 2. Results from unit-root tests on participation rates allowing for a linear trend.

\begin{tabular}{|c|c|c|c|c|}
\hline Participation rate & ADF & ADF-GLS & KPSS & Sample \\
\hline Overall & 0.0051 & -0.484 & $0.411^{* *}$ & 1984M01-2007M08 \\
\hline Men & -2.065 & -1.382 & $0.844^{* *}$ & 1948M01-2007M08 \\
\hline Women & 0.774 & -0.194 & $0.452^{* *}$ & 1948M01-2007M08 \\
\hline White & 0.695 & -0.042 & $0.486^{* *}$ & 1954M01-2007M08 \\
\hline White men & -1.665 & -1.554 & $0.851^{* * *}$ & 1954M01-2007M08 \\
\hline White women & 1.563 & 0.379 & $0.543^{* *}$ & 1954M01-2007M08 \\
\hline Black & -1.027 & -0.858 & $0.455^{* *}$ & 1972M01-2007M08 \\
\hline Black men & -2.165 & -1.788 & $0.456^{* *}$ & 1972M01-2007M08 \\
\hline Black women & -0.790 & -0.782 & $0.412^{* *}$ & 1972M01-2007M08 \\
\hline $16-24$ & -0.590 & -0.918 & $0.649^{* *}$ & 1948M01-2007M08 \\
\hline $25-54$ & 0.427 & -0.233 & $0.421^{* *}$ & 1948M01-2007M08 \\
\hline $55-64$ & -0.879 & -0.954 & $0.445^{* *}$ & 1948M01-2007M08 \\
\hline Men 16-24 & -1.439 & -1.540 & $0.771^{\text {** }}$ & 1948M01-2007M08 \\
\hline Men 25-54 & -3.170 & -0.790 & $0.347^{* *}$ & 1948M01-2007M08 \\
\hline Men 55-64 & 0.165 & -0.400 & $0.481^{* *}$ & 1948M01-2007M08 \\
\hline Women 16-24 & 0.612 & -0.195 & $0.587^{* *}$ & 1948M01-2007M08 \\
\hline Women 25-54 & 0.571 & -0.237 & $0.418^{* *}$ & 1948M01-2007M08 \\
\hline Women 55-64 & -1.906 & -0.817 & $0.377^{* *}$ & 1948M01-2007M08 \\
\hline
\end{tabular}


Allowing for a deterministic linear trend does not weaken the evidence for nonstationarity. In fact, the tests unanimously conclude that the participation rates of all subpopulations are generated by unit-root processes, even in the presence of a linear trend. Whether the data are generated by a unit-root process or a trend-stationary process has similar dire consequences for the informational value of unemployment rates though; in either case, unemployment rates alone are unlikely to be informative about the state of the labor market. ${ }^{8}$ But the lack of evidence even for trendstationarity has further important implications for the literature. In particular, simple linear detrending of the participation rates considered in this note is incorrect. ${ }^{9}$

\section{Concluding remarks}

This paper presents strong evidence against mean reversion in disaggregated participation rates of subpopulations of the US labor force. The major implication is that resorting to unemployment rates for subpopulations does not overcome the informational problems of a non-stationary aggregate participation rate. This result should be of particular concern among researchers who rely upon unemployment rates for subpopulations, such as prime-aged men, under the assumption that their participation rate is "well behaved".

It is also worth noting that our finding of a unit root in US male participation rates fits well into the to the microdata analysis of Juhn et al. $(1991,2002)$ which identifies permanent withdrawals from the labor market as the most important factor behind the secular increase in male nonparticipation since the late 1970s. ${ }^{10}$ Combined with the findings of Juhn et al. (1991, 2002) and Benati (2001) that shifts in labor force participation occur for market-driven reasons, our results are also consistent with the hypothesis that there are important, permanent, discouraged-worker effects among males in the US economy - a topic that deserves more attention in future research.

\footnotetext{
${ }^{8}$ This is of course true also for some other types of non-stationarities, such as level breaks.

${ }^{9}$ See, for example, Chan et al. (1977) for a technical discussion regarding this issue.

${ }^{10}$ Juhn et al. (1991, p. 77) even state that from the late 1970s through the 1980s "permanent withdrawals from the labor market account for all of the secular increase in nonparticipation".
} 
Based on previous research and the results in this paper, we recommend that unemployment rates be combined with other labor market statistics before conclusions are drawn about labor market conditions. At the very least, the robustness of empirical results to other measures of labor market conditions should be investigated. Examples of alternative measures are the employment rate or, ideally, some measure that in addition to the officially unemployed includes groups that are out of the labor force but who are suspected of being discouraged workers. 


\section{References}

Autor, D. H., Katz, L. F. and Kearny, M. S. (2007), “Trends in U.S. Wage Inequality: Revising the Revisionists", forthcoming in Review of Economics and Statistics.

Benati, L. (2001), "Some Empirical Evidence on the 'Discouraged Worker' Effect", Economics Letters 70, 387-395.

Blinder, A. and Esaki, H. (1978), "Macroeconomic Activity and Income Distribution in the Postwar United States", Review of Economics and Statistics 60, 604-609.

Cahuc, P. and Zylberberg, A. (2004), Labor Economics, MIT Press, Cambridge.

Chan, K. H., Hayya, J. C. and Ord, J. K. (1977), "A Note on Trend Removal Methods: The Case of Polynomial Regressions versus Variate Differencing", Econometrica 45, 737-744.

Elliott, G., Rothenberg, T. J. and Stock, J. H. (1996), "Efficient Tests for an Autoregressive Unit Root.” Econometrica 64, 813-836.

Fairlie, R. W. and Sundstrom, W. A. (1999), "The Emergence, Persistence, and Recent Widening of the Racial Unemployment Gap", Industrial and Labor Relations Review 52, 252-270.

Gould, E. D., Weinberg, B. A. and Mustard D. B. (2002), "Crime Rates and Local Labor Market Opportunities in the United States: 1979-1997”, Review of Economics and Statistics 84, 45-61.

Gustavsson, M. and Österholm, P. (2006), "The Informational Value of Unemployment Statistics: A Note on the Time Series Properties of Participation Rates", Economics Letters 92, 428-433.

Gustavsson, M. and Österholm, P. (2007), "Does Unemployment Hysteresis Equal Employment Hysteresis?”, Economic Record 83, 159-173.

Hannan, E. J. and Quinn, B. G. (1979), "The Determination of the Order of an Autoregression", Journal of the Royal Statistical Society 41, 190-195.

Jacobson, M. (2004), "Baby Booms and Drug Busts: Trends in Youth Drug Use in the United States, 1975-2000", Quarterly Journal of Economics 119, 14811512 .

Jäntti, M. (1994), "A More Efficient Estimate of the Effects of Macroeconomic Activity on the Distribution of Income", Review of Economics and Statistics 76, 372-378. 
Jaumotte, F (2003), “ Labor Force Participation of Women: Empirical Evidence on the Role of Policy and Other Determinants in OECD Countries", OECD Economic Studies, No. 37, 2003/2.

Juhn, C., Murphy, K. M., Topel, R. H. (1991), "Why Has the Natural Rate of Unemployment Increased over Time?", Brookings Papers on Economic Activity 1991:1, 75-126.

Juhn, C., Murphy, K. M., Topel, R. H. (2002), "Current Unemployment, Historically Contemplated", Brookings Papers on Economic Activity 2002:1, 79-116.

Krugman, P. R. (2004), "Checking the Facts, in Advance”, New York Times. October 12.

Kwiatkowski, D., Phillips, P. C. B., Schmidt, P. and Shin, Y. (1992), "Testing the Null Hypothesis of Stationarity Against the Alternative of a Unit Root: How Sure are We That Economic Time Series Have a Unit Root?", Journal of Econometrics 54, 159-178.

Murphy, K. M. and Topel, R. (1997), "Unemployment and Nonemployment", American Economic Review 87, 295-300.

Nicolau, J. (2002), "Stationary Processes that Look like Random Walks - The Bounded Random Walk Process in Discrete and Continuous Time", Econometric Theory 18, 99-118.

OECD (1994), Employment Outlook, OECD, Paris.

Parker, J. A. and Preston, B. (2005), "Precautionary Saving and Consumption Fluctuations", American Economic Review 95, 1119-1143.

Said, S. E. and Dickey, D. A. (1984), "Testing for Unit Roots in Autoregressive Moving Average Models of Unknown Order”, Biometrika 71, 599-607.

Wallis, K. (1987), “Time Series Analysis of Bounded Economic Variables”, Journal of Time Series Analysis 8, 115-123. 
WORKING PAPERS*

Editor: Nils Gottfries

2009:5 Lars M. Johansson and Jan Pettersson, Tied Aid, Trade-Facilitating Aid or Trade-Diverting Aid? 47pp.

2009:6 Håkan Selin, Marginal tax rates and tax-favoured pension savings of the selfemployed Evidence from Sweden. 32pp.

2009:7 Tobias Lindhe and Jan Södersten, Dividend taxation, share repurchases and the equity trap. 27pp.

2009:8 Che-Yuan Liang, Nonparametric Structural Estimation of Labor Supply in the Presence of Censoring. 48pp.

2009:9 Bertil Holmlund, Incentives in Business and Academia. 12pp.

2009:10 Jakob Winstrand, The Effects of a Refinery on Property Values - The Case of Sweden. 27pp.

2009:11 Ranjula Bali Swain and Adel Varghese, The Impact of Skill Development and Human Capital Training on Self Help Groups. 28pp.

2009:12 Mikael Elinder. Correcting Mistakes: Cognitive Dissonance and Political Attitudes in Sweden and the United States. 25 pp.

2009:13 Sören Blomquist, Vidar Christiansen and Luca Micheletto: Public Provision of Private Goods and Nondistortionary Marginal Tax Rates: Some further Results. 41pp.

2009:14 Mattias Nordin, The effect of information on voting behavior. 34pp.

2009:15 Anders Klevmarken, Olle Grünewald and Henrik Allansson, A new consumer price index that incorporates housing. $27 \mathrm{pp}$.

2009:16 Heléne L. Nilsson, How Local are Local Governments? Heterogeneous Effects of Intergovernmental Grants. 41pp.

2009:17 Olof Åslund, Per-Anders Edin, Peter Fredriksson and Hans Grönqvist, Peers, neighborhoods and immigrant student achievement - evidence from a placement policy. $27 \mathrm{pp}$.

2009:18 Yunus Aksoy, Henrique S. Basso and Javier Coto-Martinez, Lending Relationships and Monetary Policy. 42 pp.

2009:19 Johan Söderberg, Non-uniform staggered prices and output persistence. $38 \mathrm{pp}$.

2010:1 Jonathan Gemus, College Achievement and Earnings. 43 pp.

\footnotetext{
* A list of papers in this series from earlier years will be sent on request by the department.
} 
2010:2 Susanne Ek and Bertil Holmlund, Family Job Search, Wage Bargaining, and Optimal Unemployment Insurance. 30 pp.

2010:3 Sören Blomquist and Laurent Simula, Marginal Deadweight Loss when the Income Tax is Nonlinear. 21 pp.

2010:4 Niklas Bengtsson, The marginal propensity to earn, consume and save out of unearned income in South Africa. 34 pp.

2010:5 Marcus Eliason and Henry Ohlsson, Timing of death and the repeal of the Swedish inheritance tax. 29 pp.

2010:6 Teodora Borota, Innovation and Imitation in a Model of North-South Trade. $44 \mathrm{pp}$.

2010:7 Cristiana Benedetti Fasil and Teodora Borota, World Trade Patterns and Prices: The Role of Productivity and Quality Heterogeneity. 24 pp.

2010:8 Johanna Rickne, Gender, Wages and Social Security in China’s Industrial Sector. $48 \mathrm{pp}$.

2010:9 Ulrika Vikman, Does Providing Childcare to Unemployed Affect Unemployment Duration? 43 pp.

2010:10 Sara Pinoli, Rational Expectations and the Puzzling No-Effect of the Minimum Wage. 56 pp.

2010:11 Anna Persson and Ulrika Vikman, Dynamic effects of mandatory activation of welfare participants. $37 \mathrm{pp}$.

2010:12 Per Engström, Bling Bling Taxation and the Fiscal Virtues of Hip Hop. $12 \mathrm{pp}$.

2010:13 Niclas Berggren and Mikael Elinder, Is tolerance good or bad for growth? $34 \mathrm{pp}$.

2010:14 Magnus Gustavsson and Pär Österholm, Labor-Force Participation Rates and the Informational Value of Unemployment Rates: Evidence from Disaggregated USData. 10 pp.

See also working papers published by the Office of Labour Market Policy Evaluation http://www.ifau.se/ ISSN 1653-6975 